(RESEARCH ARTICLE)

\title{
The production of bioinsecticide using Bacillus thuringiensis
}

\author{
Umeaku Chinyelu Nkiru * and Ozonwankwo Chisom Franklin \\ Department of Microbiology, Chukwuemeka Odumegwu Ojukwu University, Uli, Anambra, Nigeria PMB 02.
}

Publication history: Received on 04 February 2020; revised on 24 February 2020; accepted on 27 February 2020

Article DOI: https://doi.org/10.30574/wjarr.2020.5.3.0034

\begin{abstract}
This study aims at determining the ability of Bacillus thuringiensis to induce a biocidal effect on mosquito larvae. The $B$. thuringiensis used in this work was isolated from soil samples obtained from the root of plantain trees in a garden at Umuoma community in Uli Town. Soil samples were subjected to high temperature of about $50^{\circ} \mathrm{C}$ in order to exclude other microbes that may contaminate the culture, B. thuringiensis was able to survive the heat condition because they are spore formers. To further enhance purity of the culture, the organism was cultured in Luria Bertani medium which is selective for Bacillus spp. Before the toxicity tests were carried out, various morphological tests such as endospore stain, Gram stain, macroscopic examination and biochemical tests such as starch hydrolysis, oxidase test, motility test, citrate test, methyl red test, indole test, sugar fermentation test and catalase test were carried out to identify the organism. The results showed the isolates to be Bacillus thuringiensis. To ensure the ability of the isolate to produce spores needed for toxicity testing, the isolate was subcultured in nutrient agar and incubated at $37^{\circ} \mathrm{C}$ for 7 days after which there was formation of spores in the growth medium. The isolate was then inoculated in sterile water containing mosquito larvae in other to test for its toxicity against the mosquito larvae. At intervals, observations were made to determine the rate at which the Isolates induce the lethal effects on the larvae by using the sterile loop to check for viable larva remaining at each set up. The viability is deduced from the ability of the viable larva to retain their motility when agitated with the sterile wire loop. The result for toxicity testing showed that set-up Pr1 had the highest number of dead larvae at $1-4$ hours respectively, while Gr1 had the lowest number of dead larvae at 1 . Statistical representation of the results showed that there was significant difference of $\mathrm{p} \geq 0.05$ between time and the parasporal crystals of Bacillus thuringiensis against mosquito larva. Two- factor ANOVA without replication also showed that there was a significant difference between the set-ups Pr1, Pr2, Gr1 and Db2, and the positive control used gave significant difference of $\mathrm{p}<0.05$. This study successfully demonstrated the toxicity of the parasporal crystals of Bacillus thuringiensis against mosquito larvae.
\end{abstract}

Keywords: Bacillus thuringiensis; Mosquito larvae; Toxicity; Lethal effects

\section{Introduction}

Chemical insecticides provide many benefits to food production and human health and have proven very effective at increasing agriculture and forestry productivities. They also pose some hazards as contaminants of water and food, fauna and flora (Wojciech and Korsten, 2012S). It is well documented that chemical pesticides reduced natural-enemy populations and chemical applications can disrupt biological control and may cause outbreaks of secondary pests previously suppressed by natural enemies (Bartlet, 2014).

The use of synthetic organic pesticides has caused serious economic, social and environmental problems. Economically, the rapidly increasing cost of development and production of petrochemically-derived insecticides, together with the declining effectiveness due to widespread insect resistance is alarming As a result, the chemical pesticide industry continues to develop new more expensive compounds thus increasing pesticide prices. Socially and ecologically they have caused deaths and diseases in humans and damaged the environment. It is estimated that only a minute fraction

\footnotetext{
${ }^{*}$ Corresponding author: Umeaku Chinyelu Nkiru
} 
of the insecticides applied is required for suppression of the target pest. The remainder, more than $99.9 \%$, enters the environment through soil, water and food cycles (Metcalf, 2002). Alternative methods of insect management offer adequate levels of pest control and pose fewer hazards. One such alternative is the use of microbial insecticides that contain microorganisms or their by-products. Microbial insecticides are especially valuable because their toxicity to non-target animals and humans is extremely low. Compared to other commonly used insecticides, these are safe for both the pesticide user and consumers of treated crops. Microbial insecticides also are known as biological pathogens, and biological control agents. Chemical insecticides are far more commonly used in the world than microbial control, however some microbial control agents, at least in part, can be used to replace some hazardous chemical pest control agents. A number of biological control agents formulated with bacteria, fungi, virus, pheromones, and plant extracts have been in use mainly for the control of insects responsible for the destruction of forests and agriculture crops (McDonald and Linde, 2002).

Global use of insecticides for mosquito vector control in recent decades has caused environmental pollution of aqueous ecosystem and resulted in insecticide resistance in many mosquito species. The last decade has witnessed an increased interest in biological control agents. Biological means to control vectors, based on entomopathogenic bacteria has been studied for more than 20 years. More number of biological control agents was screened for their efficacy, mammalian safety and environmental impact. Many organisms have been investigated as potential agents for vector mosquito control, including viruses, fungi, bacteria, protozoa, nematodes, invertebrate predators and fish. Only a few sporeforming bacteria, copepods and fish have reached operational use and are undergoing extensive field trials. The discovery of bacteria like $B$. thuringiensis, which is highly toxic to dipteran larvae have opened up the possibility of its use as potential biolarvicides in mosquito eradication programs all over the world (Poopathi and Tyagi, 2002). The larvicidal substances of these preparations are based on endotoxins and other proteins that have accumulated as parasporal crystals produced by the bacterial cells during the sporulation growth phase. These biological preparations have some important advantages over conventional insecticides in mosquito control operations, besides being safe to non-target organisms including human beings. Also, it is harmless to the environment (Prabakaran and Balaraman, 2006). The $B$. thuringiensis serovar israelensis has been used operationally for the control of mosquitoes for over two decades and its formulations are highly effective against Anopheles, Aedes and Culex mosquitoes (Mahmood, 2010).

This study seeks to test the ability of $B$. thuringiensis in the destruction of mosquito larva.

\section{Material and Methods}

\subsection{Sources of Sample}

In this research a total of 2 samples were used and they were obtained from agricultural and domestic sources. They include the following: rhizosphere soil of tree and garden soil samples plantain.

\subsection{Sample Collection}

2.3. Soil samples were collected from the two locations as described above from Umuoma Uli in Anambra State, using well labeled sterile sample containers and transported to the Microbiology laboratory of Chukwuemeka Odumegwu

Ojukwu University, Uli Campus within 30 minutes of collection for further analysis.

\subsection{Sterilization of Petri Dishes and other Plastic Wares}

The plastic Petri dishes and other plastic wares e.g. the test tube covers, and others were washed with detergent and water, rinsed with $70 \%$ ethanol and sterilized using a bacteriological hood with laminar air flow compartment which functions by the use of ultra-violet and electric current to create uniform velocity along parallel lines which helps in the removal of any form of contamination.

\subsection{Sterilization of Test Tubes and other Glass Wares}

The test tubes as well as other glass wares e.g. conical flask, beakers were washed with detergent and water and sterilized using hot air oven.

\subsection{Formulation of LB broth}

The LB broth was formulated using modified methods of Travers et al. (2008). The modified broth contained tryptone: $4 \mathrm{~g}, \mathrm{NaCl}: 4 \mathrm{~g}$, yeast extract: $2 \mathrm{~g}$ and was buffered with $0.25 \mathrm{M}$ sodium acetate: $3.42 \mathrm{~g}$. 


\subsubsection{Preparation}

The above listed compounds were measured and placed into a clean conical flask containing $100 \mathrm{ml}$ of distilled water which was measured with a sterile measuring cylinder; $10 \mathrm{~g}$ of each of the soil sample was added. The conical flask containing the mixture was properlycovered with cotton wool. The mixture was shaken for 4 hours on an electric shaker having speed of $150 \mathrm{rpm}$. At the end of time, $2 \mathrm{ml}$ of the soil suspension was taken and heat shocked in a water bath at $80^{\circ} \mathrm{C}$ for 20 minutes.

\subsection{Serial Dilution of Sample}

Ten-fold (10) serial dilution was used according to the methods of Cheesbrough, 2006.

\subsection{Formulation of $\mathrm{T} 3$ medium}

The T3 medium was formulated using modified methods of Travers et al. (2008), which contained tryptone: 4g, NaCl: $4 \mathrm{~g}$, yeast extract: $2 \mathrm{~g}, \mathrm{MnCl}: 0.001 \mathrm{~g}$, Agar: $5 \mathrm{~g}$ and peptone water: $0.2 \mathrm{~g}$ was used in place of tryptose. The broth was buffered with $0.05 \mathrm{M}$ sodium phosphate: $3.42 \mathrm{~g}$.

\subsection{Formulation of LB medium}

The LB medium was formulated using modified methods of Travers et al. (2008), which contained tryptone: 4g, Nacl: $4 \mathrm{~g}$, yeast extract: $2 \mathrm{~g}$, Mncl: $0.001 \mathrm{~g}$, Agar: 5 gand peptone water: $0.2 \mathrm{~g}$ was used in place of tryptose, $\mathrm{NaH}_{2} \mathrm{PO}_{4} 0.69 \mathrm{~g}$, $\mathrm{Na}_{2} \mathrm{HPO}_{4} 0.89 \mathrm{~g}$.

\subsection{Isolation of $B$. thuringiensis}

The isolate was enriched on LB broth and isolated on T3 agar and incubated for 2 days for visual evidence on growth and re-isolated on LB agar for pure culture. Careful observation was made from zero-hour till when there was visual evidence of growth on the agar plates by colony formation. See plate 1-2 for growth on T3 medium and LB medium respectively.

\subsection{Identification of the Bacterial Isolates}

The bacterial isolates were identified based on morphological, and biochemical tests characteristics.

\subsubsection{Gram staining techniques}

A thin smear of each of the pure 1-hour old cultures were prepared on clean grease-free slides, fixed by passing over gentle flame. Each heat-fixed smear was stained by addition of 2 drops of crystal violet solution for 60 seconds and rinsed with water. The smear was again flooded with Lugol's iodine for 30 seconds and rinsed with water, decolorized with $70 \%$ alcohol for 15 seconds and were rinsed with distilled water. They were then counter stained with 2 drops of safranin for 60 seconds and finally rinsed with water. This was allowed to air dry. The smears were mounted on a microscope and observed under oil immersion objective lens. Gram negative cells appeared pink or red while gram positive organisms appeared purple (Fawole and Oso, 2004).

\subsubsection{Motility Test}

Hanging drop method was utilized using a bright field microscope.

\subsubsection{Spore staining technique}

Heat-fixed smears of the organisms were prepared on separate slides and flooded with $5 \%$ malachite green solution and steamed for a minute. The stain was washed off with water and counter stained with 2 drops of safranin solutions for 20 seconds. The slides were allowed to air dry and examined under oil immersion objective lens. Endospores stained green while vegetative cells stained pink (Cheesbrough, 2006).

\subsection{Preparation of Sterile Nutrient Agar for Sporulation}

Fresh nutrient agar plates were prepared for sporulation and the plates were inoculated with B. thuringiensis. This was incubated at $37^{\circ} \mathrm{C}$ for 7 days for observation of spores.। 


\subsection{Toxicity Testing}

Aseptically, 120 mosquito larvae were collected from stagnant water. Colonies of $B$. thuringiensis from the nutrient agar plate were transferred using a sterile inoculating wire loop into test tubes containing $10 \mathrm{ml}$ of sterile water. 20 larvae of mosquitoes, $5 \mathrm{ml}$ suspension of $B$. thuringiensis spores and $100 \mathrm{ml}$ of normal saline were set up in duplicate $250 \mathrm{ml}$ conical flask. A replicate with no bacteria was prepared as negative control; $1 \mathrm{ml}$ of sniper insecticide was introduced into another flask containing 20 larvae and $100 \mathrm{ml}$ of normal saline this served as a positive control. The set up was allowed to stand for 1, 2 and 48 hours respectively. Larval motility was verified by counting living versus the dead larva. The larvae that did not move when touched with a sterile stick were considered dead.

\section{Results}

\subsection{Isolation Bacillus thuringiensis}

Bacillus thuringiensis was isolated on T3 medium and LB medium respectively.

\subsection{Identification of Bacillus thuringensis}

Table 1, 2 and Figure 1-2 shows the results for the biochemical and morphological tests conducted.

Table 1 Biochemical tests

\begin{tabular}{|l|c|c|}
\hline Biochemical Tests & Pr1 & Gs1 \\
\hline Oxidase & $+\mathrm{VE}$ & $+\mathrm{VE}$ \\
\hline Catalase & $+\mathrm{VE}$ & $+\mathrm{VE}$ \\
\hline Citrate & $+\mathrm{VE}$ & $+\mathrm{VE}$ \\
\hline Gas & $-\mathrm{VE}$ & $-\mathrm{VE}$ \\
\hline $\mathrm{H} 2 \mathrm{~S}$ & $-\mathrm{VE}$ & $-\mathrm{VE}$ \\
\hline Indole & $-\mathrm{VE}$ & $-\mathrm{VE}$ \\
\hline Voges-proskauers test & $-\mathrm{VE}$ & $-\mathrm{VE}$ \\
\hline Starch hydrolysis test & $+\mathrm{Ve}$ & $+\mathrm{Ve}$ \\
\hline
\end{tabular}

Key: +VE = Positive; $-\mathrm{VE}$ = Negative; Pr1= Plantain root sample; Gs1= Garden soil sample

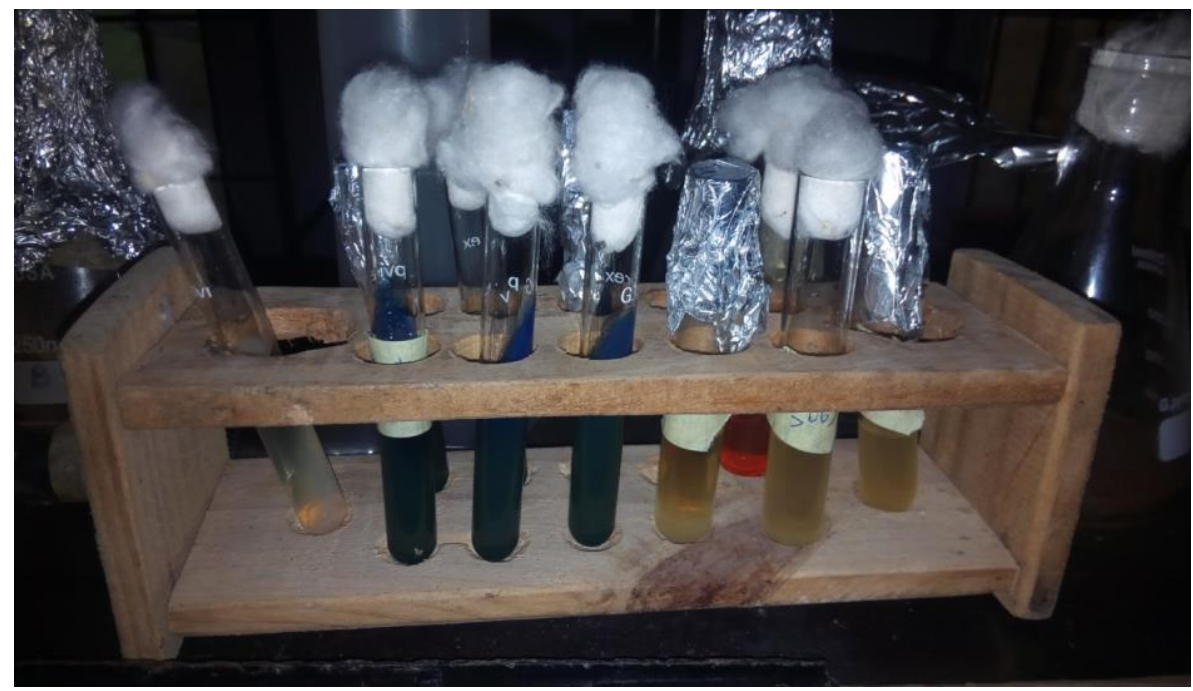

Figure 1 Simmons' citrate Agar containing the Isolate showing positive after $24 \mathrm{~h}$ 
Table 2 Morphological characteristics of isolates

\begin{tabular}{|l|c|c|}
\hline Morphology & Pr1 & Gs1 \\
\hline Aerobic growth & $+\mathrm{VE}$ & $+\mathrm{VE}$ \\
\hline Gram staining & $+\mathrm{VE}$ & $+\mathrm{VE}$ \\
\hline Structure & Rods & Rods \\
\hline Motility & Motile & Motile \\
\hline Spore & $+\mathrm{VE}$ & $+\mathrm{VE}$ \\
\hline
\end{tabular}

Key: +VE = Positive; -VE = Negative; Pr1= Plantain root sample; Gs1= Garden soil sample

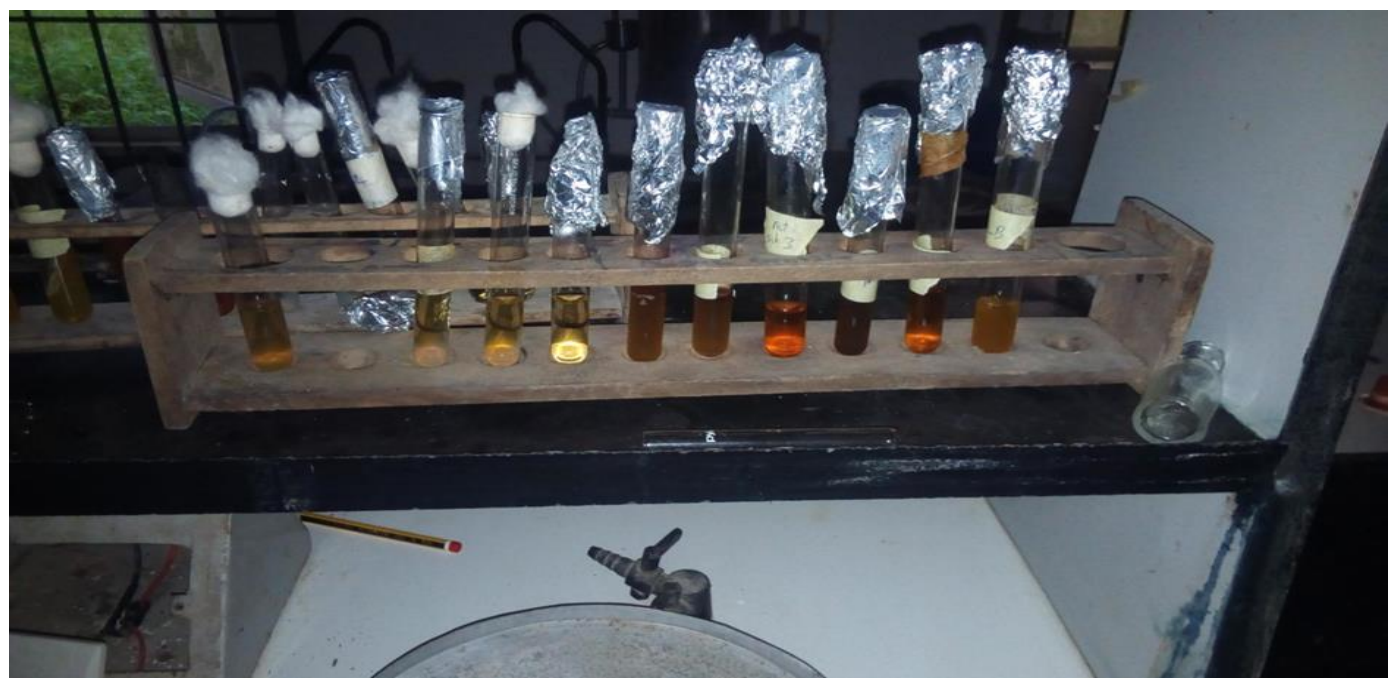

Figure 2 Biochemical test set up including indole, motility and sugar fermentation showing positive after $24 \mathrm{~h}$

\subsection{Toxicity Testing}

Tables $3-4$ and Figures 3-6 show the results of toxicity tests. The tests were monitored for 1, 2 and 4 hours' interval respectively.

Table 3 Toxicity test for different set-ups at 1 hours

\begin{tabular}{|l|l|l|l|}
\hline Set up & $\begin{array}{l}\text { Frequency of the dead } \\
\text { mosquito } \\
\text { Larvae }\end{array}$ & $\begin{array}{l}\text { Frequency of live } \\
\text { mosquito larvae }\end{array}$ & $\begin{array}{l}\text { Percentage frequency of } \\
\text { dead mosquito larvae \% }\end{array}$ \\
\hline Pr1 & 15 & 5 & 75 \\
\hline Pr2 & 7 & 13 & 35 \\
\hline Gs1 & 5 & 15 & 25 \\
\hline Gs2 & 4 & 16 & 20 \\
\hline
\end{tabular}


Table 4 Toxicity test for different set-ups at 2 hours

\begin{tabular}{|l|l|l|l|}
\hline Set-up & $\begin{array}{l}\text { Frequency of the dead } \\
\text { mosquito larvae }\end{array}$ & $\begin{array}{l}\text { Frequency of live } \\
\text { mosquito larvae }\end{array}$ & $\begin{array}{l}\text { Percentage frequency of } \\
\text { dead mosquito larvae \% }\end{array}$ \\
\hline Pr1 & 16 & 4 & 80 \\
\hline Pr2 & 8 & 12 & 40 \\
\hline Gs1 & 7 & 13 & 35 \\
\hline Gs2 & $5 \quad 15$ & 25 \\
\hline
\end{tabular}

Table 5 Toxicity test for different set-ups at 4 hours

\begin{tabular}{|l|l|l|l|}
\hline $\begin{array}{l}\text { Experimental } \\
\text { design }\end{array}$ & $\begin{array}{l}\text { Frequency of the dead } \\
\text { mosquito larvae }\end{array}$ & $\begin{array}{l}\text { Frequency of live } \\
\text { mosquito larvae }\end{array}$ & $\begin{array}{l}\text { Percentage frequency of } \\
\text { dead mosquito larvae \% }\end{array}$ \\
\hline Pr1 & 18 & 2 & 90 \\
\hline Pr2 & 15 & 3 & 75 \\
\hline Gs1 & 13 & 7 & 65 \\
\hline Gs2 & 11 & 9 & 55 \\
\hline
\end{tabular}

\subsection{Statistical Analysis}

A Two- factor ANOVA without replication was done and the result showed that there was a significant difference between the experiments (Pp1, Pr2, Gs1 and Gs2) and the positive control used i.e. $\mathrm{p}<0.05$.

Table 6 Two- Factor ANOVA without replication table

\begin{tabular}{|l|l|l|l|l|l|l|}
\hline SUMMARY & Count & Sum & Average & Variance & & \\
\hline Pr1 & 3 & 245 & 81.66667 & 58.33333 & & \\
\hline Pr2 & 3 & 150 & 50 & 475 & & \\
\hline Gs1 & 3 & 125 & 41.66667 & 433.3333 & & \\
\hline Gs2 & 3 & 100 & 33.33333 & 358.3333 & & \\
\hline & & & & & & \\
\hline Column 1 & 4 & 155 & 38.75 & 622.9167 & & \\
\hline Column 2 & 4 & 180 & 45 & 583.3333 & & \\
\hline Column 3 & 4 & 285 & 71.25 & 222.9167 & & \\
\hline ANOVA & & & & & & \\
\hline $\begin{array}{l}\text { Source } \\
\text { Variation }\end{array}$ & SS & df & MS & F & P-value & F crit \\
\hline Rows & 4016.667 & 3 & 1338.889 & 29.66154 & 0.000538 & 4.757063 \\
\hline Columns & 2379.167 & 2 & 1189.583 & 26.35385 & 0.001068 & 5.143253 \\
\hline Error & 270.8333 & 6 & 45.13889 & & & \\
\hline & & & & & & \\
\hline Total & 6666.667 & 11 & & & & \\
\hline
\end{tabular}


Table 7 The ANOVA table showing the methods used in analyzing data

\begin{tabular}{|l|l|l|l|l|}
\hline Sum of squares & DF & MS & \multicolumn{1}{|c|}{ F-ratio } & \\
\hline Factor A & SS-A & A-1 & SS-A/DF-A & MS-A/MS-W \\
\hline Factor B & SS-B & B-1 & SS-B/DF-B & MS-B/MS-W \\
\hline I.E & SS-I & $(A-1)^{*}(B-1)$ & SS-I/DF-I & MS-I/MS-W \\
\hline W.G & SS-W & N-AB & SS-W/DF-W & \\
\hline Total & SS-T & N-1 & & \\
\hline
\end{tabular}

Where I.E=Interaction Effect; W.G=Within Group; Percentage frequency of dead Mosquito larva= X / N * 100/1

Where $\mathrm{N}=$ total number of larva for a specific isolate; $\mathrm{X}=$ number of dead larva for a

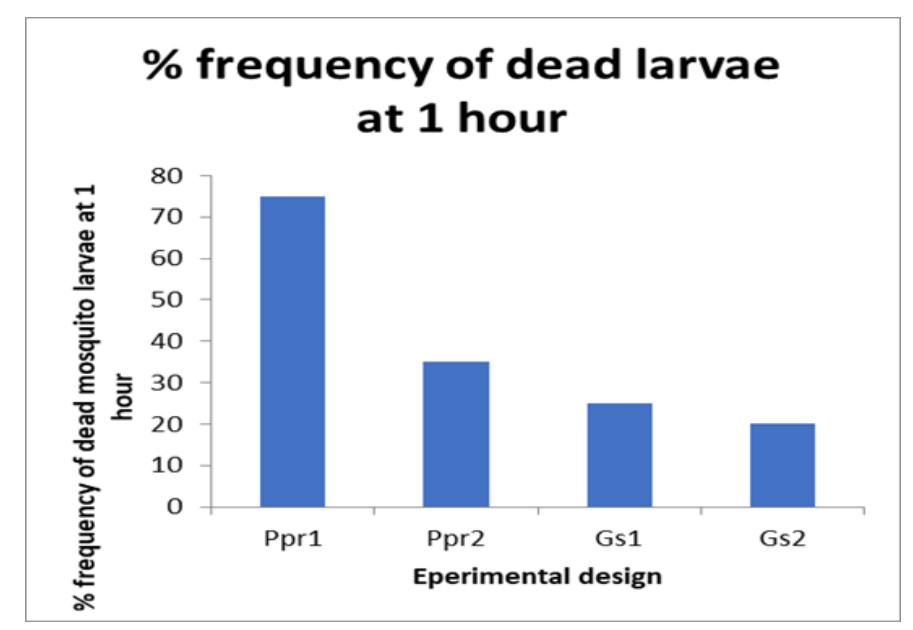

Figure 3 Percentage frequency of dead larva at each experimental design at 1 hour interval

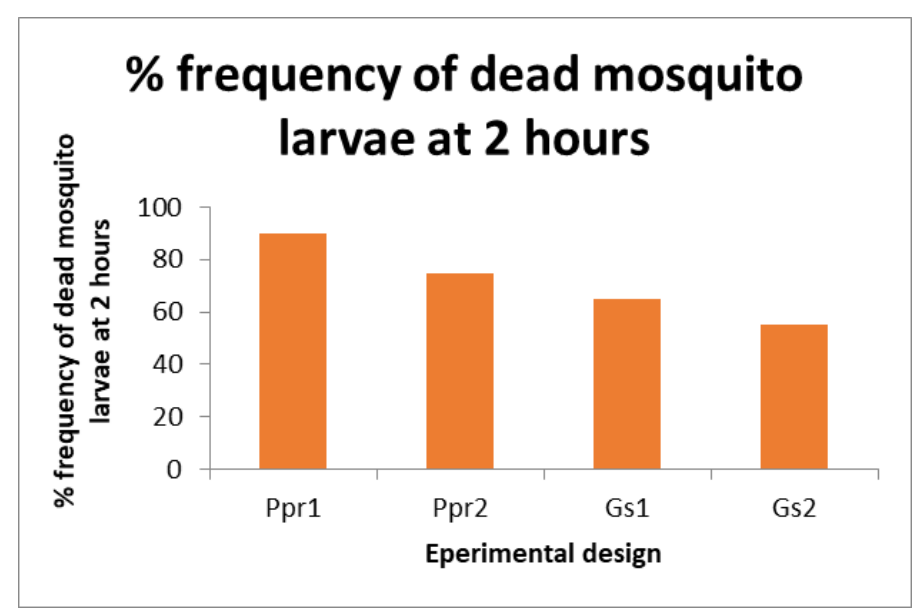

Figure 4 Percentage frequency of dead larva at each experimental design at 2 hour interval 


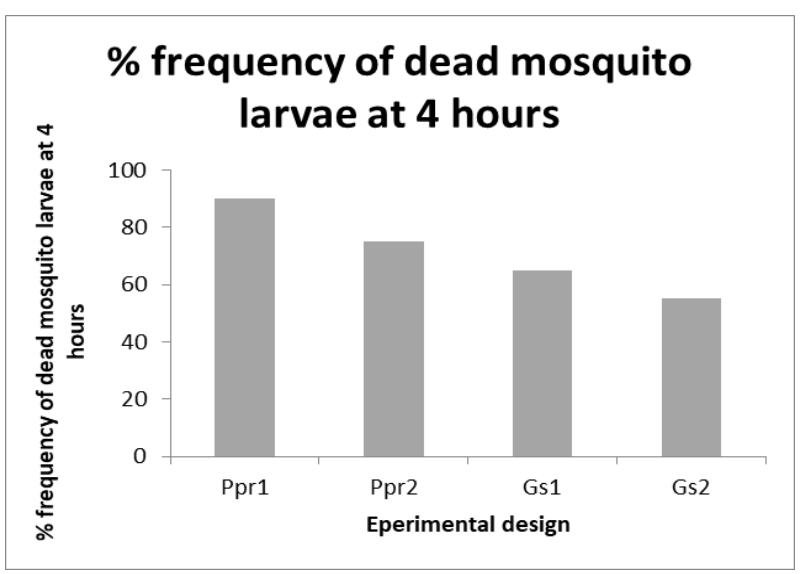

Figure 5 Percentage frequency of dead larva at each experimental design at 4 hours interval

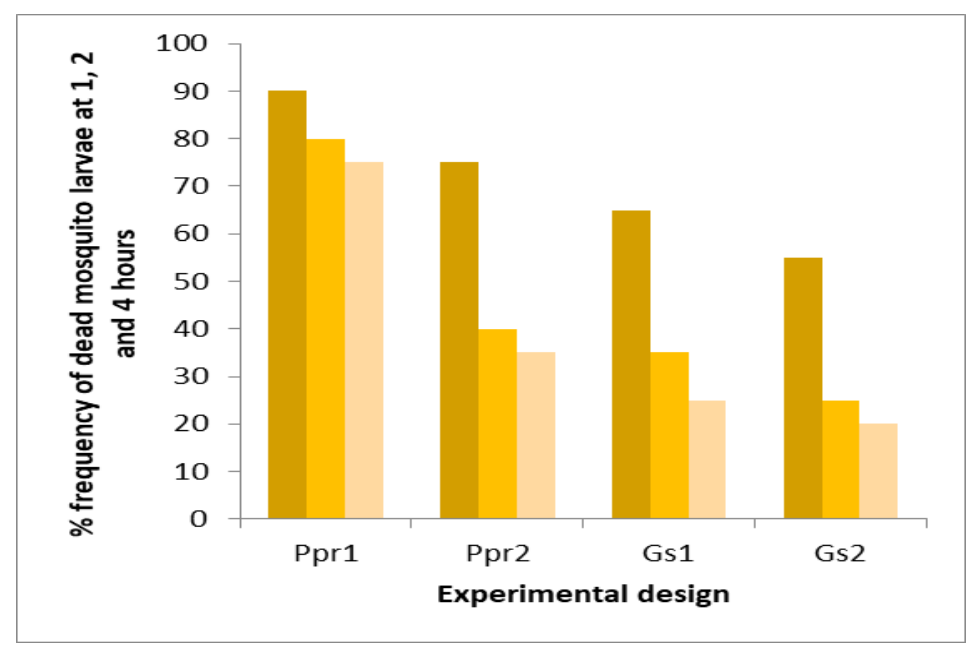

Figure 6 Frequency of dead larva at each experimental design at 1, 2 and 4 hour's interval

\section{Discussion}

Mosquitoes are vectors of the etiology of Malaria disease. Studies carried out by Bartlet (2014) on the chemical control of Mosquitoes revealed that the chemical methods induce the formation of recalcitrant, resistance strains and environmental hazards. The study also revealed that the chemical factors are often difficult to procure hence, giving rise to the need to establish a safer and cheap biological control.

The presence of Bacillus thuringiensis in the studied soil samples gotten from the root soil of plantain tree and Garden plants could be attributed to the secretion of root exudates in the plant Rhizosphere which contains nutrients required for growth of Bacillus thuringiensis (Kreig, 2009).

In accordance to the results established by Johnson et al. (2008) work on this topic, the highest occurrence of this organism in the plantain root soil sample collected is attributed to the greater secretion of exudates that favours the growth of Bacillus thuringiensis in the rhizosphere.

Similar findings were reported by many researchers (Baum et al.,2001; Bernhard et al., 2002; Chilcott., 2003; Konwles et al., 2008). Chilcott (2003) reported the presence of Bacillus thuringiensis from soil sample gotten from the root of plantain trees when they studied Biocontrol potentials of the organism against insects. They equally discussed the chemical components of plant exudates in the rhizosphere which is the sole factor bringing about the growth of the organism in that region the he carried out an experiment to evaluate the difference between the biomass of the organism in the rhizosphere and that in the edaphosphere. They discovered that the biomass is more in the rhizosphere than in 
the edaphosphere. They went further to attribute this result to the difference in amount of plant exudates present in both sides.

The significant mortality rate caused by Bacillus thuringiensis on the insect larva can be attributed to the secretion of parasporal crystals by the Bacillus thuringiensis which are highly toxic to the larva of mosquito, the toxicity is due to presence of polypeptide toxins in the crystals (Travers et al., 2008).

The highest toxicity observed after $4 \mathrm{~h}$ of exposure can be attributed to the high accumulation of the parasporal crystals, due to the fact that increased concentration of the crystal will induce increase in mortality rate.

\section{Conclusion}

The present study was successful in detecting the toxicity of Bacillus thuringiensis toxin on mosquito larvae, and to formulate a biopesticide from a cheap (free) source which is soil containing nutrient and presence of this Bacillus thuringiensis which can be used to produce large scale of biopesticides. So the results obtained from this study are very promising and will be very useful in developing efficient Bacillus thuringiensis biopesticides in Nigeria.

\section{Compliance with ethical standards}

\section{Acknowledgments}

I am grateful to the Vice Chancellor, Chukwuemeka Odumegwu Ojukwu University, Anambra State and to the Department of Microbiology, Uli Campus for their support.

\section{Disclosure of conflict of interest}

There is no conflict of interest amongst the authors

\section{References}

[1] Amusan AAS, Mafiana CF, Idowu AB and Oke OA. (2007). A survey of adult mosquitoes in the hostels of the University of Agriculture, Abeokuta, Ogun state Nigeria. Nigerian Journal of Parasitology, 24, 167-172.

[2] Aronson AT and Fitz-James P. (2012). Structure and morphogenesis of the bacterial spore coat. Biological Reviews, 40, 360-402.

[3] Aronson IA, Beckman W and Dumn P. (2007). Bacillus thuringiensis and related insect pathogens. Microbiolgical Reviews, 50, 1-24.

[4] Barjac DH and Frachon E. (2003). Classification of Bacillus thuringiensis and distribution in soil of the United States. Canadian Journal of Microbiology, 27, 865-870.

[5] Bartlet BR. (2014). Integration of chemical and biological control. Journal of Biological Control Of Insect Pests and Weeds, 20, 489-511.

[6] Baum JA, Johnson TB and Carlton BC. (2001). Bacillus thuringiensis: natural and recombinant bioinsecticide products. Journal of Biopesticide Use and Delivery, 4, 189-210.

[7] Bergdoll M. (2004). Bacillus cereus Food-Borne Disease.Clinical Microbiology News letter, 3, 85 - 87.

[8] Bernhard K, Jarrett P, Meadows M, Butt J, Ellis DJ, Roberts GM, Pauli S, Rodgers P and Burges HD. (2002).Natural isolates of Bacillus thuringiensis. worldwide distribution, characterization and activity against insect pests. Journal Invertebrate Pathology, 70, 59-68.

[9] Burges HD and Pillai JS. (2009). Microbial bioinsecticides. Microbial Technology in the Developing World, 50, 3455.

[10] Carozzi NB, Johnasen T, Lecadet MM and Kolsto AB. (2000). Prediction of Insecticidal activity of Bacillus thuringiensis strains by polymerase chain reaction product profile. Application Enviromental Microbiology, 57, 3057-3061.

[11] Cheesbrough M. (2006). District Laboratory Practice in Tropical Countries. Second Edition. Cambridge University Press, Cambridge, United Kingdom, 113-200. 
Umeaku and Ozonwankwo / World Journal of Advanced Research and Reviews, 2020, 05(03), 001-012

[12] Chilcott CN, Knowles BH, Ellar DJ and Drobniewski FA. (2003). Mechanism of action of Bacillus thuringiensis subsp israelensis parasporal body. In Bacterial Control of Mosquito and Black flies, 4, 45-65.

[13] Claus D and Berkeley RCW. (2007). Genus Bacillus. Bergey's Manual of Systematic Bacteriology, 2, 1110-1137.

[14] Cooksey KE. (2000). Identification of parasporal crystal protein using biochemical method. Journal Application Microbiology, 6, 440-445.

[15] Couch TL and Ross DA. (2005). Production and utilization of B. thuringiensis. Biotechnology and Bioegineering, 22, 1297-1304.

[16] Drobniewski FA. (2001). A review: the safety of Bacillus species as insect vector control agents. Journal Application Bacteriology, 76, 101-109.

[17] Elmer W, Stephen D, William M, Paul C and Washington C. (2002). Diagnostic Microbiology. Fifth Edition. McGraw-hill companies, New York, 113-117.

[18] Estes ZE and Faust R.M. (2004). The Production of crystal toxins from Bacillus thuringiensis. Journal Invertebrate Pathology, 8, 139-145.

[19] Fawole MO and BA Oso. (2004). Characterization of bacteria. Laboratory Manual of Microbiology. Fourth Edition., Spectrum Book Ltd., Ibadan, Nigeria, 24-33.

[20] Goldberg IJ and Margalit J. (2007). A bacterial spore demonstrating rapid larvicidal activity against Anopholese sergentii, Vranotaenia unquiculata, Culex uniritattus, Aedes aegypti and Culex pipiens. Mosquito News, 37, 355358.

[21] Heimpel AM (2000). A critical review of Bacillus thuringiensis var. thuringiensis (Berliner) and other crytalliferous bacteria. Annual Review Entomology, 12, 287-322.

[22] Ignoffo CM and Garcia C. (2001). UV-photoinactivation of cells and spores of Bacillus thuringiensis and effect of peroxide on Inactivation. Environmental Entomology, 7, 270-272.

[23] Ignoffo CM, Hastetter DL, Pinneli RF and Garcia C. (2007). Relative susceptibility of six soybean caterpillars to standard preparation of Bacillus thuringiensis var. Kurstaki. Journal of Economic Entomology, 70, 60-65.

[24] Itoua CA, Drif L, Vassal JM, Barjac H, Bossy JP, Leclant F and Fructose R. (2008). Isolation of multiple subspecies of Bacillus thuringiensis from population of European sunflower moth. Homoeosoma nebulella, 61, 4343-4347.

[25] Johnson KR, Scriber JM, Nitas JK and Smitely DR. (2008). Toxicity of Bacillus thuringiensis var kurstaki to three non-target Lepidopteran insects in field study. Environmental Entomology, 24, 288-291.

[26] Jorge EI, Cristina M, Sergio O, David N, Graciela B, Rose M, Leda R, Claudia MF, Humberto L, Mario HR, Jorge S, Guadalupa P and Alejandra B. (2003). Diversity of Bacillus thuringiensis strains from Latin America with insecticidal activity against different mosquito species. Applied and Enviromental Microbiology, 69, 5269-5274.

[27] Kaelin P, Morel P and Gadani F. (2001). Isolation of Bacillus thuringiensis from stored tobacco and Lasioderma serricorne. Applied Enviromental Microbiology, 61, 3063-3068.

[28] Knowles BH and Ellar DJ. (2009). Colloid osmotic lysis as general feature of mechanism of action of Bacillus thuringiensis $\alpha$-endotoxins. Biochemical et Biophysical Acta, 924, 509-578.

[29] Knowles BH, Blatt MR, Horsnell JM, Corrol J, Tester M, Menestrina G and Ellar DJ. (2008). Acytolytic $\alpha$-endotoxin from Bacillus thuringiensis var israelensis from cation selective channels in planar lipid bilayer. Biochemical et Biophysical Acta, 244, 259-262.

[30] Krieg A. (2009). Diseases caused by bacteria and other prokaryotes. Epizootiology of Insect Disease. International Biology Review, 8, 323-355.

[31] Krieg AA, Huger G, Longenbruch M and Schnetter W. (2007). Bacillus thuringiensis var tenebrionis, a new pathogen effective against larvae of Cleoptera. Journal of Applied Entomology, 96, 500 -508.

[32] Labaw LW. (2011).The structure of Baillus thuringiensis (Berliner) crystals. Journal Ultrastructure Research, 10, $66-75$.

[33] Leonard C, Yahua C and Mahilion J. (2002). Diversity and distribution of IS231, IS232 and IS240 among B. cereus, B. thuringiensis and B. mycoides. Journal of Microbiology, 143, 2537-2547.

[34] Lereclus D, Delecluse A and Lecadet M. (2003). Diversity of Bacillus thuringiensis toxins and genes. Theory and Practice, 25, 37-69. 
Umeaku and Ozonwankwo / World Journal of Advanced Research and Reviews, 2020, 05(03), 001-012

[35] Mahmood F. (2002). Laboratory bioassay to compare susceptibilities of Aedes aegypti and Anopheles albimanus to Bacillus thuringiensis var. israelensis as affected by their feeding rates. Journal American Mosquito Control Association, 14, 69-71.

[36] Margalit J and Dean D. (2006). The story of Bacillus thuringiensis var. israelensis. Journal of American Mosquito Control Association, 1, 1-7.

[37] Martin PAW and Travers RS. (2008). Worldwide abundance and distribution of Bacillus thuringiensis Isolates. Applied and Environmental Microbiology, 55, 2437-2442.

[38] McDonald BA and Linde C. (2002). Pathogen population genetics, evolutionary potential, and durable resistance. Annual Review of Phytopathology, 40, 349-379.

[39] Meadows MP. (2003). Bacillus thuringiensis in the environmental: ecology and risk assessment. Theory and Practice, 25, 73-78.

[40] Meadows MP, Ellis DJ, Butt J, Jarrett P and Burges HD. (2000). Distribution, frequency and diversity of Bacillus thuringiensis in An animal feed mill. Applied Enviromental Microbiology, 58, 1344-1350.

[41] Merchant IA and Packer RA. (2000). The Bacillus genus. veterinary bacteriology and virology. The Lowa State University Press, Ames, Lowa U.S.A, 386.

[42] Metcalf RL. (2002). The Ecology of Insecticides and the Chemical Control of Insects. Ecological Theory and Integrated Pest Managment in Practice, 32, 251297.

[43] Michael DK, Seleena B, Han LL and Sarjeet SG. (2008). Isolation and identification of novel toxins from Malaysia, Bacillus thuringiensis subsp jegathean. Journal Applied Enviromental Microbiology, 61, 2965-2969.

[44] Olutiola PO, Famurewa O and Sonntag HG. (2000). Introduction to General Microbiology: A Practical Approach. Second Edition.,Bolabay Publications, Ikeja, Nigeria, 120-121.

[45] Pendleton IR and Morrison RB. (2000). The toxin of parasporal crystal, Journal Applied Bacteriology, 30, 396402.

[46] Poopathi S and Tyagi BK. (2002). Studies on Bacillus sphaericus toxicity-related resistance development and biology in the filariasis vector, Applied Entomological Zoology, 3, 365-371.

[47] Prabakaran G and Balaraman K. (2006). Development of a cost-effective medium for the large scale production of Bacillus thuringiensis var. israelensis. Biological control, 36, 288-292.

[48] Quinn JP, Markey BK, Carter ME, Donnelly WJ and Leonard FC. (2002). Veterinary microbiology and microbial Disease. Blackwell Science Journal, 12, 129-130.

[49] Schnepf E, Crickmore N, VanRie J, Lereclus D, Baum J, Feitelson J, Zeigler DR and Dean DH. (2009). Bacillus thuringiensis and its pesticidal crystal proteins. Microbial Molecular Biology Review, 62, 775-806.

[50] Sliman R, Rehm S and Shalses DM. (2009). Serious Infection caused by Bacillus spp. Journal of Medicine, 66, 218223.

[51] Smirnoff WA. (2000). The pesticidal crystal toxin of Bacillus spp. Journal Insect Pathology, 5, $235-242$.

[52] Smith NR, Gordon RE and Clark FE. (2002). Aerobic Spore-Forming Bacteria. Journal of Microbiology, 67, 120121.

[53] Tabashnik BE. (2001). Evolution of resistance to Bacillus thuringiensis. Annual Review Entomology, 79, $100-110$.

[54] Takken W, Snellen WB, Verhaue JP, Knols BGJ, Atmosoedjono S, Swellengrebel NH and Kuipers J. (2003). Environmental measures for malaria control in indonesia. A Historical Review on Species Sanitation, 3, 21-34.

[55] Terranova W and Blake PA. (2001). Bacillus cereus Food poisoning. Journal Medicals, 298, 143-144.

[56] Travers RS, Martin PAW and Reichelerfer CF. (2008). Selective process for efficient isolation of soil Bacillus spp. Journal of Applied and Environmental Microbiology, 53, 1263-1266.

[57] Tuason CU, Murray HW and Levy C. (2009). Serious infection for Bacillus species. Journal of American Mosquito control Agent, 241, 1137-1140.

[58] Van Rie J, Mcguanghey WH, Johnson DE, Barnett BD and van Mellaert H. (2003). Mechanism of insect resistance to the microbial insecticide Bacillus thuringiensis. Science, 247, 72-74. 
Umeaku and Ozonwankwo / World Journal of Advanced Research and Reviews, 2020, 05(03), 001-012

[59] Wojciech JJ and Korsten L. (2002). Biological Control of Postharvest Diseases of Fruits. Annual Review of Phytopathology, 40, 411-441.

[60] Young M and Mandelstam J. (2009). Early events during bacterial endospore formation. Advances in Microbial Physiology, 23, 104-162.

\section{How to cite this article}

Umeaku CN and Ozonwankwo CF. (2020). The production of bioinsecticide using Bacillus thuringensis. World Journal of Advanced Research and Reviews, 5(3), 01-12. 